\title{
Biologic width-A Review
}

Bhochhibhoya A ${ }^{1}$, Shrestha $\mathrm{R}^{2}$

${ }^{1}$ Lecturer, Department of Dentistry, Tribhuvan University Dental Teaching Hospital, Institute of Medicine, Tribhuvan University, Kathmandu, Nepal.

${ }^{2}$ Lecturer, Periodontology and Oral Implantology Unit, Department of Dental Surgery, National Academy of Medical Sciences, Kathmandu, Nepal.

\begin{abstract}
Replacement of missing, damaged or unaesthetic tooth by dental prostheses helps the patient to rehabilitate structure and function of the lost tissues. During delivery of the prostheses, the overall health of the oral tissues, including the periodontium, must be considered. The gingival tissues must be healthy and it is of paramount importance to respect the biologic width of the tissues. The biologic width varies among different individuals and at different sites of the same individual. Instead of following a mean value, each patient should be examined to determine the biologic width. In case violation of biologic width is anticipated, appropriate measures should be adopted to maintain the dimensions of the biologic width.
\end{abstract}

Key words: Biologic width; Crown lengthening; Margins; Orthodontic extrusion.

\section{Introduction}

$\mathrm{D}$ ental prostheses are used for the restoration of damaged, unaesthetic, or dysfunctional tooth, or to replace one or more missing natural teeth. ${ }^{1}$ While prostheses serve to cater optimal quality of life to the individual, faulty prostheses, on the other hand, contribute to detriment the periodontium. ${ }^{2}$ Tooth and prostheses related factors have been introduced as a separate category in the recent American Academy of Periodontology (AAP) Classification of Periodontal and Peri-implant Diseases and Conditions as other conditions affecting the periodontium under Periodontal Diseases and conditions. $^{3}$

\section{*Corresponding Author}

Dr. Rejina Shrestha, Lecturer

Periodontology and Oral Implantology Unit,

Department of Dental Surgery, National Academy of

Medical Sciences, Kathmandu, Nepal

E-mail: rejinashrestha811@gmail.com
Localised dental-prosthesis-related factors predisposing to periodontitis include: ${ }^{4}$

a) Restoration margins placed within the supracrestal attached tissues

b) Clinical procedures related to the fabrication of indirect restorations

c) Hypersensitivity/toxicity reactions to dental materials

Dental prostheses should be fabricated harmonising with the natural hard and soft tissues. Infringement of the periodontal tissues results in loss of the supporting tissues. The dimension of the soft tissue, which is attached to the portion of the tooth coronal to the crest of the alveolar bone, termed biologic width ${ }^{5}$, should be preserved. Histologically, the biologic width is composed of the junctional epithelium and supracrestal connective tissue attachment. The AAP 2017 has replaced the term supracrestal tissue attachment and the term biologic barrier has been suggested. ${ }^{6}$ Maintenance of biological width is essential for the optimal periodontal health, which again is dependent on the properly designed restorations. ${ }^{7}$ 


\section{Definitions of Biological Width:}

Khuller N and Sharma N (2009) ${ }^{8}$ defined BW as the dimension of the soft tissue, which is attached to the portion of the tooth coronal to the crest of the alveolar bone.

Nevin and Skurow $(1984)^{9}$ defined it as the sum of the combined supracrestal fibers, the junctional epithelium and the sulcus.

World Workshop on the classification of Periodontal and Peri implant diseases and conditions (2018) defined it as a commonly used clinical term to describe the apico- coronal variable dimensions of the supracrestal attached tissues.

The concept of biologic width must be clear as many clinicians are unable to practically implement it. ${ }^{10}$ In dentistry, the area of biological width is sometimes called Bermuda Triangle or Devil's Triangle. ${ }^{11,12}$

\section{History}

Gottlieb was the first to describe the "epithelial attachment". ${ }^{13}$ The "gingival crevice" or sulcus was defined by Orban and Mueller ${ }^{14}$. The connective tissue was described as threedimensionally oriented fibers firmly connecting tooth structures to the adjacent gingiva by Feneis. ${ }^{15}$ Marfino, Orban and Wentz ${ }^{16}$ were the first to demonstrate that gingival connective tissue attachment and junctional epithelium compose the attachment of gingiva to tooth. Sicher ${ }^{17}$ described the dentogingival junction as epithelial and connective tissue attachments to the teeth.

Historically Walter Cohen first coined the term "biologic width" and in 1977, Ingber et al. described the biologic width. ${ }^{18}$ In 1961, Garguilo et al. ${ }^{19}$ evaluated the average vertical dimensions of the biological width. From 30 autopsy specimens, 287 individual teeth were studied and the alveolar crest, the connective tissue attachment, the epithelial attachment, and the sulcus depth were measured. They reported the mean sulcus depth of $0.69 \mathrm{~mm}$, epithelial attachment of $0.97 \mathrm{~mm}$, and connective tissue attachment of $1.07 \mathrm{~mm}$. The biologic width was calculated to be $2.04 \mathrm{~mm}$. Thus, on average, it is essential to maintain $3 \mathrm{~mm}$ distance from the bone crest to the cement-enamel junction in healthy teeth or until the end of the preparation or the margin of restoration in restored teeth. ${ }^{20}$

Vacek et $\mathrm{al}^{21}$ reported variations in the dimensions of the supracrestal gingival tissue between teeth and in different sites within the same tooth. They evaluated 171 cadaver tooth surfaces and observed mean measurements of $1.34 \mathrm{~mm}$ for sulcus depth, 1.14 for epithelial attachment, and $0.77 \mathrm{~mm}$ for connective tissue attachment. The connective tissue attachment was the most consistent measurement. Vacek and colleagues found that the biological width increased anteroposteriorly and $15 \%$ of restoration that impinge the biologic width had a biologic width of less than $2.04 \mathrm{~mm}$.

The dimensions advocated by different authors to maintain a healthy gingiva are shown in Table 1.

Table 1: Minimum biologic width advocated by various authors

\begin{tabular}{|c|c|}
\hline Authors & $\begin{array}{l}\text { Minimum } \\
\text { requirement }\end{array}$ \\
\hline Ingber et al $(1977)^{18}$ & $3 \mathrm{~mm}$ \\
\hline $\begin{array}{l}\text { Rosenberg and colleagues (1980 } \\
\text { and 1999) })^{22}\end{array}$ & 3.5 to $4 \mathrm{~mm}$ \\
\hline Weinberg and Eskow $(2000)^{23}$ & 3.5 to $4 \mathrm{~mm}$ \\
\hline Nevins \& Skurow $(1984)^{9}$ & $3.0 \mathrm{~mm}$ \\
\hline $\begin{array}{l}\text { Wagenberg and colleagues } \\
(1989)^{24}\end{array}$ & 5 to $5.25 \mathrm{~mm}$ \\
\hline Palomo and Kopczyk 25 & $1 \mathrm{~mm}$ \\
\hline
\end{tabular}

Interproximal Biologic Width is similar to that of the facial surface but the total dentogingival complex is different. According to Kois and Spear, the dentogingival complex is $3.0 \mathrm{~mm}$ facially and $4.5 \mathrm{~mm}$ to $5.5 \mathrm{~mm}$ interproximally. ${ }^{26}$ The height of interdental papilla was explained 
by increased scalloping of the bone. Spear suggested that additional 1.5 to $2.5 \mathrm{~mm}$ of interproximal gingival tissue height is seen only in the presence of adjacent teeth. In the absence of the adjacent tooth, the interproximal gingival tissue be $3.0 \mathrm{~mm} .^{26}$ Tarnow and colleagues found that the distance from the contact point to alveolar crest should not exceeded $5 \mathrm{~mm}$ to $5.5 \mathrm{~mm}$ for the gingival tissue to completely fill the interdental space. Greater distance resulted in significant loss of alveolar height. ${ }^{27}$ Cho et al also found that the number of papillae that filled the interproximal space also decreased as the interproximal distance between the teeth increased. ${ }^{28}$

\section{Importance of biologic width}

The components of the biologic width serve for adhesion of the junctional epithelium and insertion of the connective fibers to the dental structure. ${ }^{5}$ They create a barrier in the periodontium and prevent microbial penetration. If it is impinged, the microorganisms gain access to deeper tisssues and cause destructive inflammation. The restorations with rough surface aid in retention of the biofilm and the inability of the patient to clean deep areas further aggravates the biofilm accumulation. As a consequence, gingival inflammation, loss of clinical attachment, bone loss, gingival recession, increasing vertical bone resorption and increasing the horizontal component can be seen. ${ }^{29}$

Violation of biologic width results in: ${ }^{30}$

a) Crestal bone loss

b) Gingival recession with localized bone loss

c) Localized gingival hyperplasia with minimal bone loss

d) A combination of three

Tooth supported/retained restorations and their design, fabrication, delivery, and materials can be associated with plaque retention and loss of clinical attachment. However, according to the available evidence, it is not possible to determine if the negative effects is due to dental plaque biofilm, trauma, toxicity of dental materials, or a combination of these factors. ${ }^{4}$

Optimal restoration margins located within the gingival sulcus do not cause gingival inflammation if patients are compliant with self-performed plaque control and periodic maintenance. Localized inflammation that does not respond to adequate measures of plaque control may be a sign of dental material hypersensitivity. ${ }^{4}$

\section{Evaluation of Biologic Width Violation}

\section{Clinical method}

The presence of discomfort during examination of restoration margins indicates biologic width violation. The clinical signs of biologic width violation are:

a) Chronic progressive gingival inflammation around the restoration

b) Bleeding on probing

c) Localized gingival hyperplasia with minimal bone loss

d) Gingival recession

e) Pocket formation

f) Clinical attachment loss

g) Alveolar bone loss

h) Gingival hyperplasia

Encroachment of restoration into biologic width initiates crestal bone resorption. This occurs to allow space for establishment of a minimum biologic width. ${ }^{31}$

\section{Radiographic evaluation}

Radiographs are useful non-invasive tools in the assessment of biological width encroachment. Their use is only limited to interproximal areas. Parallel profile radiographic (PPR) technique has been introduced to measure the dimensions 
of the dento gingival unit (DGU) ${ }^{32}$ It is used to measure both length and thickness of the DGU.

\section{Bone sounding}

After application of local anesthesia, the area is probed till the bone is felt. Then, the sulcus depth is measured and subtracted. If the distance is less than $2 \mathrm{~mm}$, biologic width violation can be confirmed. ${ }^{33}$ The transulcular periodontal probing was described by Jardini and Pustiglione. ${ }^{34}$ The following considerations must be considered for bone sounding:

1. The gingiva must be healthy.

2. The measurement should be repeated on more than one tooth to ensure accurate assessment, and reduce individual and site variations.

\section{Factors influencing the biologic width ${ }^{5,35-37}$}

a) Location/inclination of the tooth in the socket

b) Different teeth

c) Site of the tooth

d) Gingival biotype

e) Keratinised tissue

\section{Categories of biologic width: ${ }^{35}$}

There are three categories of biologic width

\section{Normal crest patient}

The maximum number of individuals, i.e., $85 \%$ of the individuals have normal crest patient. The gingival tissues are stable for a long-term. In these cases, when the crown margin is placed $0.5 \mathrm{~mm}$ subgingivally, it is tolerated well by the gingiva.

\section{High crest patient}

It is seen in $2 \%$ of the individuals and is found in a proximal surface adjacent to an edentulous site. If the margins are placed subgingivally in these cases, the margins will be closer to alveolar bone and biologic width is violated.

\section{Low crest patient}

It is seen in $13 \%$ of the individuals. If the margins are placed subgingivally in these cases, there might be two types of reaction based on the depth of the sulcus. If the attachment apparatus is thick and the sulcus is shallow, it is less susceptible to gingival recession and if the attachment apparatus is narrow with deeper sulcus, it is more susceptible to gingival recession.

\section{Dimensions of periodontium}

Maynard and Wilson ${ }^{38}$ categorised the periodontium into three-dimensions

- Superficial physiologic: It represents the free and attached gingiva surrounding the tooth.

- Crevicular physiologic: It represents the gingival dimension from the gingival margin to the junctional epithelium.

- Subcrevicular physiologic: It is analogous to the biologic width and consists of the junctional epithelium and connective tissue attachment.

\section{Types of margin}

Margins can be placed in three ways:

\section{Supragingival margin}

This margin type is easy for preparation of the tooth and finishing of the margin. The impression can be taken easily with proper duplication of the margins. The margins are mainly given in non-esthetic areas owing to the color and opacity contrast present in restorative materials. If translucent restorative materials are used, they can also be given in esthetic areas. They are the least irritating to the periodontal tissue.

\section{Equigingival margin}

The restoration and the tooth margin can be blended easily. Tooth preparation and finishing is easy and it gives a smooth, polished interface at the gingival margin. But, traditionally, it was 
said to favour accumulation of plaque giving rise to gingival inflammation. ${ }^{5}$

\section{Subgingival margin}

Subgingival margins should be given if dental caries or tooth deficiencies extend apically beyond the gingival crest. ${ }^{39}$ It is also used for optimal esthetic output. But, too far placement of the subgingival margin will impinge on the periodontal apparatus. Constant inflammation occurs and the condition is aggravated by the patient's inability to clean this area. Biologic width violation will lead to gingival recession and bone loss. Thin alveolar bone increases the risk of alveolar bone loss and thin gingiva increases the risk of gingival recession. ${ }^{5}$ The more common finding with deep margin placement is unchanged bone level but gingival inflammation will develop and persist on the restored tooth. ${ }^{40}$ This type of margin is not accessible for finishing and polishing which acts as a niche for bacterial growth. ${ }^{41}$ To prevent these complications, the contour should be proper, polishing of the restoration should be done and biologic width must be respected. The amount of attached gingiva should also be taken into account.

\section{Margin placement ${ }^{42}$}

1. If the sulcus probes $1.5 \mathrm{~mm}$ or less, the restorative margin could be placed $0.5 \mathrm{~mm}$ below the gingival tissue crest.

2. If the sulcus probes $>1.5 \mathrm{~mm}$, the restorative margin can be placed in half the depth of the sulcus.

3. If the sulcus is $>2 \mathrm{~mm}$, gingivectomy could be performed to lengthen the tooth, and create a $1.5 \mathrm{~mm}$ sulcus. Then the patient can be treated as per rule 1 .

In a study done by Valderhaug and Birkeland ${ }^{41}$, 114 patients with 329 total crown restorations were evaluated. $59 \%$ of the crowns were located subgingivally at the beginning of the study period and after 5 years, only $32 \%$ of the crown margins remained below the gingival margin.

Waerhaug stated that subgingival restorations are plaque-retentive areas and are inaccessible to scaling instruments. They will continue to accumulate plaque even after adequate supragingival plaque control measures are carried out. Later, he demonstrated that gingivitis and attachment loss was associated with sub marginal restorations in monkeys and dogs. ${ }^{43}$ Clinical and histological observations of human teeth was done by Dragoo and Williams ${ }^{44}$. They demonstrated that compared to shoulder preparations, compromised healing was associated with gingival bevel crown margins. Orkin et al. ${ }^{42}$ demonstrated that subgingival restorations had a greater chance of bleeding and gingival recession than supragingival restorations. Stetler and Bissada ${ }^{45}$ demonstrated that teeth with subgingival restorations and narrow zones of keratinized gingiva showed significantly higher gingival index scores than teeth with sub marginal restorations with wide zones of keratinized gingiva. Keratinised gingiva should be carefully evaluated before plcing subgingival restorations.

Flores-de-je-Coby et $\mathrm{al}^{46}$ demonstrated that subgingival margins demonstrated increased plaque, gingival index scores, and probing depths. More spirochetes, fusiforms, rods, and filamentous bacteria were found to be associated with subgingival margins.

\section{Method to correct biologic width violation}

The biologic width has inter-personal and intrapersonal variability. There is no magic number which can be recommended and each site of each patient must be evaluated before coming to a definite conclusion. ${ }^{47}$ In case a biologic width is violated, the following procedures should be considered: 
1. Surgical crown lengthening:

- Gingivectomy

- Apically positioned flap (APF)

- APF with osseous reduction

2. Orthodontic procedure

- Forced eruption

- Forced eruption combined with fiberotomy

- Orthodontic Extrusion associated with Supracrestal Fiberotomy and Root Planing (OEFRP):

\section{Surgical crown lengthening}

As the term indicates, it is used to lengthen the crown. Various measures are:

\section{Gingivectomy}

External bevel gingivectomy is both successful and predictable surgical procedure and is indicated in hyperplasia or pseudopocket along with presence of adequate amount of keratinized tissue. ${ }^{48}$ Internal bevel gingivectomy is carried out if reduction of excessive pocket depth and exposure of coronal tooth is required in absence of sufficient zone of attached gingiva. ${ }^{8}$

\section{Apically positioned flap (APF)}

Apically positioned flap is recommended when crown lengthening of multiple teeth in a quadrant or sextant of dentition is required and there is a biologic width of more than $3 \mathrm{~mm}$. Pocket reduction can be done at the same surgery. It should not be done for during surgical crown lengthening of a single tooth in the esthetic zone.

\section{APF with osseous reduction}

It is the most common procedure for clinical crown lengthening. It is done in inadequate zone of attached gingiva and biologic width less than $3 \mathrm{~mm}$. Detailed evaluation should be done before carrying out osseous reduction as it compromises periodontal support of the tooth, causes furcation involvement, poor crown-to- root ratio and gingival recession. It should not be done during surgical crown lengthening of a single tooth in the esthetic zone. In such cases, forced eruption should be considered to prevent negative architecture.

\section{Orthodontic procedures}

\section{Forced eruption}

In forced eruption, tooth is intentionally moved in a coronal direction using gentle continuous force. The force stretches gingival and periodontal fibers resulting in a coronal shift of gingiva and bone. ${ }^{49}$ It was first advocated by Heithersay ${ }^{49}$ for teeth with horizontal fractures. Orthodontic extrusion was advocated in anterior area where surgical crown lengthening cannot be accomplished. It minimizes gingival recession and loss of bone support on adjacent teeth. ${ }^{50,51}$

Orthodontic extrusion requires an activation period of 4-6 weeks and 6-8 weeks retention period for tooth to become stabilized in its new position. Additional surgical crown lengthening may be required after forced eruption. The contraindications are inadequate crown-to-root ratio, lack of occlusal clearance and periodontal complications.

\section{Forced eruption with fiberotomy}

Combination of orthodontic extrusion and severance of supracrestal fibers, termed supracrestal fiberotomy is also used for crown lengthening. If fibrotomy is performed during the forced tooth eruption procedure, the crestal bone, and the gingival margin are retrieved at their pretreatment location. Thus, the toothgingiva interface at adjacent teeth is unaltered. Fibrotomy is performed once every 7-10 days during the phase of forced tooth eruption. ${ }^{27}$

Orthodontic Extrusion associated with Supracrestal Fiberotomy and Root Planing (OEFRP): It is a flapless technique for crown lengthening after orthodontic extrusion. The OEFRP procedure must be carried out every 2 
weeks during the entire extrusive orthodontic phase. $^{52}$

\section{Complications after crown lengthening ${ }^{5}$}

a) Poor aesthetics due to 'black triangles'

b) Root hypersensitivity

c) Root resorption

d) Transient mobility of the teeth

\section{Conclusion}

The study of the periodontal-prosthodontic relationship is necessary for the ultimate success of the prostheses. The maintenance of the normal structure of the biological tissues should be done and the concept of biologic width must be followed at each procedure. The periodontal health is an important key for the longevity of dental prostheses.

\section{References}

1. Zhao J, Wang X. Dental prostheses. In: Advanced ceramics for dentistry 2014; (pp. 2349). Butterworth-Heinemann.

2. Deepa D, Sangwan N, Gothi R. Effect of Faulty Prosthesis on Periodontium-A Case Report. Saudi J Oral Dent Res. 2016;1(2):54-7.

3. Caton JG, Armitage G, Berglundh T, Chapple IL, Jepsen S, Kornman KS, Mealey BL, Papapanou PN, Sanz M, Tonetti MS. A new classification scheme for periodontal and periimplant diseases and conditions-Introduction and key changes from the 1999 classification. J Clin Periodontol. 2018; 45:45(Suppl 20):S1-8.

4. Jepsen S, Caton JG, Albandar JM, Bissada NF, Bouchard P, Cortellini P, Demirel K, de Sanctis M, Ercoli C, Fan J, Geurs NC. Periodontal manifestations of systemic diseases and developmental and acquired conditions: Consensus report of workgroup 3 of the 2017 World Workshop on the Classification of Periodontal and Peri-Implant Diseases and Conditions. J Clin Periodontol. 2018; 45:45(Suppl 20): S219-29.

5. Nugala B, Kumar BS, Sahitya S, Krishna PM. Biologic width and its importance in periodontal and restorative dentistry. J Conserv Dent. 2012;15(1):12-7.
6. Parashar A, Zingade A, Sanikop S, Gupta S, Parasher S. Biological width: The silent zone. Int Dent J Stud Res. 2015;2:11-5.

7. Thomas S, Sampat P, Agarwal S. Biological Width-Exploring the Mystery of a Silent Zone. Journal of Dental and Medical Sciences. 2018; 17:38-45.

8. Khuller N, Sharma N. Biologic width: Evaluation and correction of its violation. J Oral Health Community Dent. 2009;3:20-5.

9. Nevins M, Skurow HM. The intracrevicular restorative margin, the biologic width, and the maintenance of the gingival margin. Int $\mathrm{J}$ Periodontics Restorative Dent. 1984;3:31-49.

10. Robbins JW. Tissue management in restorative dentistry. Funct Esthet Restor Dent. 2007;1:403.

11. Ambegaokar N, Shetty A, Shetty d, Shah J. Biologic width violation- a wake up call literature review. Int J Curr Res. 2018;10(3):67212-6.

12. Sharma A, Rahul GR, Gupta, B, Hafeez M. Biological width: No violation zone. Eur J Gen Dent. 2012,1:137-41.

13. Gottlieb B. Der Epithelansatz am Zahne. Dtsch Monatsschr Zahnheilk.1921; 39:142-7.

14. Orban B and Mueller E. The gingival Crevice. J Am Dent Assoc.1929; 16:1206.

15. Feneis H. Anatomy and physiology of the normal gingiva. Dtsch Zahnarztl Z. 1952;7:46776.

16. Marfino NR, Orban BJ, Wentz FM. Repair of the dento-gingival junction following surgical intervention. J Periodontol.1959; 30: 180-90.

17. Sicher H. Changing concepts of supporting dental structures. Oral Surg Oral Med Oral Pathol. 1959 Jan;12(1):31-5.

18. Ingber JS, Rose LF, Coslet JG. The "biologic width" - a conceptin periodontics and restorative dentistry. Alpha Omegan. 1977;70:62-5.

19. Gargiulo AW, Wentz FM, Orban B. Dimensions and relations of the dentogingival junction in humans. J Periodontol. 1961;32:261-7.

20. Jorgic-Srdjak K, Plancak D, Maricevic T, Dragoo MR, Bosnjak A. Periodontal and prosthetic aspect of biological width part I: Violation of biologic width. Acta Stomatol Croat. 2000;34:195-7 
21. Vacek JS, Gher ME, Assad DA. The dimensions of the human dentogingival junction.Int $\mathrm{J}$ Periodontics Restorative Dent. 1994;14:154-65.

22. Rosenberg ES, Cho SC, Garber DA. Crown lengthening revisited. Compend Contin Educ Dent. 1999;20:527.

23. Weinberg MA, Eskow RN. An overview of delayed passive eruption Compend Contin Educ Dent. 2000;21(6):511-4.

24. Wagenberg BD. Surgical tooth lengthening: Biologic variables and esthetic concerns. J Esthet Dent. 1998;10:30-6.

25. Palomo F, Kopczyk RA. Rationale and methods for crown lengthening. J Am Dent Assoc. 1978;96(2):257-60.

26. Cohen ES. Atlas of cosmetic and reconstructive surgery. 2007; 3rd edition:245.

27. Tarnow DP, Magner AW, Fletcher P. The effects of the distance from the contact point to the crest of bone on the presence or absence of the interproximal dental papilla. J Periodontol. 1992;63:995.

28. Cho HS, Jang HS, Kim DK, Park JC, Kim HJ, Choi SH, Kim CK, Kim BO. The effects of interproximal distance between roots on the existence of interdental papillae according to the distance from the contact point to the alveolar crest. J Periodontol. 2006;77(10):1651-7.

29. Felippe LA, Monteiro Júnior S, Vieira LC, Araujo E. Reestablishing biologic width with forced eruption. Quintessence. 2003;34:733-8

30. de Waal H, Castellucci G. The importance of restorative margin placement to the biologic width and periodontal health. Part II. Int $\mathrm{J}$ Periodontics Restorative Dent. 1994;14(1)46171.

31. Poddar S, Bagchi S, De A, Rambabu D, S.R. Savan, Chowdhury M. Clinical Significance of Biologic Width in Perio-Restorative Dentistry: A Review. J Adv Med Dent Scie Res. 2018;6(8):82-4.

32. Galgali SR, Gontiya G. Evaluation of an innovative radiographic techniqueparallel profile radiography- to determine the dentogingival unit. Indian $\mathrm{J}$ Dent Res. 2011;22:237-41.

33. Frank M Spear, Joseph P Cooney. Periodontalrestorative interrelationships. In Michael $G$
Newman, Henry H Takei, Fermin A Carranza, editors. Carranza. 9th edition. Philadelphia: WB saunders;2002.p.951-953.

34. Jardini MAN, Pustiglioni FE. Estudo biometrico do espaco biologico emhumanos por meio da sondagem transulcular. Rev Pos Grad. 2000;7(4):295-302.

35. Kois JC. Altering gingival levels: The restorative connection, Part I: Biologic variables. J. Esthet Dent. 1994;6:3-9.

36. Cook DR, Mealey BL, Verrett RG, Mills MP, Noujeim ME, Lasho DJ, Cronin RJ Jr. Relationship between clinical periodontal biotype and labial plate thickness: an in vivo study. Int $J$ Periodontics Restorative Dent. 2011;31(4):345-54.

37. Carvalho BA, Duarte CA, Silva JF, da Silva Batista WW, Douglas-de-Oliveira DW, de Oliveira ES, de Goés Soares L, Galvão EL, Rocha-Gomes G, Glória JC, Gonçalves PF. Clinical and radiographic evaluation of the Periodontium with biologic width invasion. BMC oral health. 2020;20(1):1-6.

38. Maynard JG Jr, Wilson RD. Physiologic dimensions of the periodontium significant to the restorative dentist. J Periodontol. 1979;50:170-4

39. Tylman SD: Theory and practice of crown and bridge prosthodontics, ed 5, St Louis, 1965, Mosby.

40. Waerhaug J. Healing of the dento-epithelial junction following subgingival plaque control.II: As observed on extracted teeth. J Periodontol. 1978;49:119-34.

41. Valderhaug J, Birkeland JM. Periodontal conditions in patients 5 years following insertion of fixed prostheses. Pocket depth and loss of attachment. J Oral Rehabil. 1976;3:237-43.

42. Orkin DA, Reddy J, Bradshaw D. The relationship of the position of crown margins to gingival health. J Prosthet Dent. 1987;57:421-4.

43. Waerhaug, J. Temporary restorations: advantages and disadvantages. Dent Clin N Am. 1980;24:305-6.

44. Dragoo MR, Williams GB. Periodontal tissue reactions to restorative procedures. Int $\mathrm{J}$ Periodontics Restorative Dent. 1981; 1(1):8-23.

45. Stetler KJ, Bissada NF. Significance of the width of keratinized gingiva on the periodontal 
status of teeth with submarginal restorations. J Periodontol. 1987;58(10):696-700.

46. Flores-de-Jacoby L, Zafiropoulos GG, Ciancio $\mathrm{S}$. Effect of crown margin location on plaque and periodontal health. Int J Periodontics Restorative Dent. 1989;9(3):197-205.

47. Schmidt JC, Sahrmann P, Weiger R, Schmidlin PR, Walter C. Biologic width dimensions-a systematic review. J Clin Periodontol. 2013;40(5):493-504.

48. Smukler H, Chaibi M. Periodontal and dental considerations in clinical crown extension: A rationale basis for treatment. Int $\mathrm{J}$ Periodont Restor Dent. 1997;17:464-77.
49. Heithersay GS. Combined endodonticorthodontic treatment of transverse root fractures in the region of the alveolar crest. Oral Surg Oral Med Oral Pathol. 1973;36:404-15.

50. Ingber JS. Forced eruption, part II. J Periodontol. 1974;45:199-206.

51. Ingber JS. Forced eruption, part $1 \mathrm{~J}$ Periodontol. 1976;47:203-16.

52. Braga G, Bocchieri A. A new flapless technique for crown lengthening after orthodontic extrusion. Int J Periodontics Restorative Dent. 2012; 32:81-90. 